\title{
PUBLIC-PRIVATE PARTNERSHIP AS A MECHANISM INNOVATIVE DEVELOPMENT OF THE DIGITAL ECONOMY OF THE REPUBLIC OF UZBEKISTAN
}

\author{
Yangiboy Burikulovich Mustafakulov \\ Lecturer Art. Rev. Agtu (Russia) Branches In Tashkent Region (Uzbekistan) Tashkent Region, Uzbekistan
}

\section{ABSTRACT}

The article deals with the peculiarities of formation and development of public-private partnership in the development of the national economy. The directions of innovative development are defined. The problems that need to be solved for the development of innovative economy are highlighted.

KEYWORDS: - Innovation, innovative economy, public-private partnership.

\section{INTRODUCTION}

Currently, Uzbekistan is implementing the Action Strategy for five priority areas of the country's development until the end of 2021. This Strategy defines ensuring the balance and stability of the national economy, increasing the share of industry, services, small business and private entrepreneurship in its structure. Along with this, it is planned to conduct an active investment policy aimed at modernization, technical and technological renewal of production, implementation of projects of production, transport, communication and social infrastructure [1].

As you can see, the successful implementation of the measures provided for in the Action Strategy will require significant investments. One of the ways to attract investments to solve the tasks outlined in the Action Strategy is the widespread use of public-private partnerships (PPPs). In the general case, PPP is a special way of combining the resources of business and the state, in which the greatest efficiency of achieving public interests is achieved in terms of the rational use of available resources, while creating a separate object of public importance due to its use to satisfy the interests of society, as well as a commercial value for investors. Therefore, the PPP mechanism can be attributed to investment mechanisms.

\section{T HE MAIN RESULTS AND FINDINGS}


CURRENT RESEARCH JOURNAL OF PEDAGOGICS 2(12): 16-21, December

2021 DOI: https://doi.org/10.37547/pedagogics-crjp-02-12-04

ISSN 2767-3278

(C)2021 Master Journals

Crossref do: 81 Google

Accepted 05 ${ }^{\text {th }}$ December, 2021 \& Published $10^{\text {th }}$ December, 2021

PPP is indeed an effective mechanism for increasing the competitiveness of the national economy by attracting significant investments to modernize existing and create new production facilities, to master the latest technologies, including in management. As the most important direction for solving the problems of creating and using PPP as an institution for modernizing the national economy, it is advisable to develop a unified state approach, which should form the basis of the state concept for the development of PPP in Uzbekistan.

Currently, Uzbekistan has created a legal basis for the development of PPPs. In particular, in 2018, a special Resolution of the President of the Republic of Uzbekistan "On priority measures to create a legal and institutional framework for the development of public-private partnership" was adopted, and in 2019 the Law "On public-private partnership" was adopted. That is, the country has created legal and institutional conditions for the formation and development of PPP. In our opinion, the most promising areas for the implementation of public-private partnership in Uzbekistan are: school and preschool education, higher education, construction of residential buildings, construction and operation of highways, reconstruction of housing and communal services, development of telecommunications infrastructure, health care and social services. The main instruments for the implementation of PPP projects are concession agreements, special economic zones, the creation of technoparks and others.

At the same time, for the effective development of PPPs, mutual attraction of the state and the private sector is required. For Uzbekistan, the PPP concept is relatively new, which implies the existence of different approaches to the PPP itself. We can talk about the presence of two directions. The first approach assumes that PPP can be understood as any interaction between business and the state, for example, in the form of supply of goods for the needs of ministries and departments. In the second approach, PPP is viewed primarily as a form of project financing. This approach is closest to foreign understanding and use of the PPP concept.

In our opinion, it is the second approach that is most adequate for the implementation of the Strategy for the innovative development of the economy of Uzbekistan. The adoption of this Strategy is caused by the fact that the rapidly developing all spheres of public and state life of Uzbekistan require close support of ongoing reforms based on modern innovative ideas, developments and technologies that ensure a quick and high-quality breakthrough of the country among the 50 advanced countries of the world [2].

When developing and implementing modern strategies for innovative development, great importance is attached to the creation of organizational and legal prerequisites for the formation of partnerships that unite in various combinations private industrial companies, universities, government departments and independent research laboratories to jointly achieve specific scientific and technological results. Private sector investment in infrastructure has steadily increased in recent years in many developing countries. This is ensured by the participation of business in joint infrastructure projects with the state, which brings good results. Thanks to this, conditions are created for the introduction of new technologies, the budgetary burden is reduced, and control over the accuracy of project implementation is enhanced [4].

In our opinion, the national innovation system should be presented in the form of a system of relationships between science, industry and society, when innovations serve as the basis for economic development. At the same time, the needs of innovative development, in turn, largely 
CURRENT RESEARCH JOURNAL OF PEDAGOGICS 2(12): 16-21, December

2021 DOI: https://doi.org/10.37547/pedagogics-crjp-02-12-04

ISSN 2767-3278

(C)2021 Master Journals

\section{Crossref do) 81 Google}

Accepted 05th December, 2021 \& Published 10 th December, 2021

determine and stimulate the most important directions for the development of scientific activity. In its most general form, the structure of the innovation system should include various interconnected organizations engaged in the production and implementation of scientific knowledge and technologies within national borders. These may include small and large companies, universities, laboratories, technology parks and incubators, as well as legal, financial and social institutions that provide innovative processes.

PPP can be extremely effective in implementing the strategy for the development of an innovative type of economy. Such a model assumes the effective development of innovations, new technologies, types of products and resources, as well as the implementation of organizational and institutional projects in the field of national reproduction. For Uzbekistan, the need to impart innovative qualities to the economy stems from the goal set in the above-mentioned Strategy Uzbekistan's entry by 2030 into the 50 advanced countries of the world. The stated goal can be achieved in the future only by ensuring the proper level of economic freedom, creating equal conditions for competitiveness, strengthening property rights, as well as the effective integration of government, science, education and business [2].

The course taken by Uzbekistan for the innovative development of the economy requires the formation of mechanisms for multilateral interaction between government bodies, business, scientific and educational organizations. This is not an easy task, as there is currently no such experience.

In our opinion, to ensure an integrated approach to the use of tools to support innovation and expand the practice of PPP participation in the implementation of innovative projects, it is advisable to carry out a lot of organizational work. First of all, it is required to comprehensively study the issues of development and implementation of the state scientific, technical and innovation policy.

In addition, it is advisable to assess the effectiveness of PPP development in the innovation and educational spheres. It is important to note that a number of factors affect the expansion of the scale and forms of interaction between the state and business in the innovation sphere.

- firstly, PPP provides an opportunity to involve the resources of the private sector in the reproduction processes in sectors and spheres owned by the state and regional authorities, as well as to use private entrepreneurial initiative for the efficiency of spending budget funds;

- secondly, it allows to combine the efforts and resources of private business and the state within the framework of specific PPP projects and forms their additional competitive advantages.

The listed factors indicate that in the long term it is possible to predict, in general, an increase in the scale, development and diversification of PPP forms. Private business is interested in maximizing profits from the implementation of innovative projects, since, having economic freedom in projects provided by the state, the private sector seeks to increase labor productivity and implement innovations [3].

In our opinion, business, in comparison with state institutions, has greater mobility, efficiency in making managerial decisions and the ability to generate innovations. The government, in turn, can ensure more successful implementation of PPP projects by creating a more stable regulatory framework, government guarantees, stimulating innovative development of taxation and other types of support.

In turn, the state is interested in the 
CURRENT RESEARCH JOURNAL OF PEDAGOGICS 2(12): 16-21, December

2021 DOI: https://doi.org/10.37547/pedagogics-crjp-02-12-04

ISSN 2767-3278

(C)2021 Master Journals

Crossref doi) 81 Google

Accepted 05th December, 2021 \& Published 10 th December, 2021

development of PPP projects, since the state and regional budgets receive an additional source of income from revenues from rent and concession payments, as well as in the redistribution of part of the costs of maintaining and investing property in the private sector [5].

Unlike many countries that have confidently taken the path of innovative development, in Uzbekistan, innovative projects are not being actively implemented. Consequently, it is necessary to coordinate efforts in terms of creating an innovative infrastructure, developing innovative entrepreneurship, improving the interaction of state authorities with existing components of the innovative infrastructure, which include research and educational centers, infrastructure for financing innovation and innovative companies. PPP mechanisms should serve as the basis for interaction.

The experience of using public-private partnership in scientific, technological and innovation spheres in Western European countries shows that this mechanism is used where the state and business have complementary interests, but at the same time are not able to act completely independently and independently of each other [6].

In practice, the most common forms of PPP are co-financing of research projects at an early stage, when industry participation is incentivized to transfer rights to research and development results for their further commercialization. In some cases, co-financing of the early stages of commercialization occurs through the creation of joint research centers in areas that are traditionally under the responsibility of the state, for example, in health care, environmental protection and others. PPP management is quite complex, therefore, from the very beginning, it is important to determine the areas of responsibility of the state and private business and provide mechanisms for their revision that do not pose a significant risk to any of the parties.

It is important to keep in mind that in order to ensure the innovative development of the national economy, it is necessary to develop a set of strategic priorities and directions that provide for the innovative development of the economy. When choosing a strategic direction, the role of public-private partnership in the formation of an innovative economy is established. That is, in this case, one should choose a path of economic development that is capable of changing the trajectory of reproduction from an extensive to an intensive type of development based on the introduction of innovations in the field of technology, technology, labor organization and management into production. Such a transition from the current state to an innovative path of development will make it possible to effectively master intellectual capital, which, together with other resources, is capable of creating, building and creating new social values. At the same time, the task of science is to develop new technologies and introduce them into production, and the role of the state is to create the necessary conditions for the development of PPP in the country. A special role is also assigned to the education system, which must be able to train competitive specialists capable of creating innovations, and the state and business together must create all the necessary conditions for the implementation of this process.

Given the lack of experience in the application of PPP projects in Uzbekistan, it is important to highlight the problems that need to be addressed. The problems of public-private partnership in the field of innovative development of the economy arise from the existing objective factors and risks of using PPP in the implementation of innovative projects. These problems include the following:

- firstly, insufficient experience in the 
CURRENT RESEARCH JOURNAL OF PEDAGOGICS 2(12): 16-21, December

2021 DOI: https://doi.org/10.37547/pedagogics-crjp-02-12-04

ISSN 2767-3278

(C)2021 Master Journals

Crossref doi) 81 Google

Accepted 05th December, 2021 \& Published 10 th December, 2021

implementation of effective interaction between public and private business;

- secondly, the imperfection of the existing legislation in the country;

- thirdly, the lack of sufficient experience in resolving issues related to the provision of tax incentives to organizations involved in innovative activities and implementing intellectual property objects in the domestic and market, and stimulating consumers of high technology products, and others. In our opinion, in the future, scientific and technological innovations carried out in the PPP format in Uzbekistan should be aimed at the formation and implementation of new high-tech industries, promising technologies and materials. As for innovations in education, they should be aimed at the formation of a developed, innovationoriented and competitive specialist.

\section{Conclusion}

It seems to us that the priority areas of PPP in Uzbekistan are promising infrastructure projects in the scientific, technological and educational spheres that can ensure the innovative development of the economy. The most important condition for the successful implementation of structural transformations and attracting private investment in the field of science and technology is the government's implementation of an effective innovation and scientific and technological policy in terms of developing a regulatory framework, supporting fundamental and applied research, mastering and disseminating scientific research, taking into account strategic, economic and social interests. In Uzbekistan, the most valuable potential of using the mechanisms of public-private partnership, which can become a catalyst for innovative development of the economy, as well as significantly increase the level of socioeconomic development of the country, is still insufficiently used. An essential feature of PPP is that it creates additional motivation for private investors to organize competitive high-tech production in various regions of the country with high scientific, technical and innovative potential.

Thus, for the active participation of PPPs in the formation and development of an innovative economy in Uzbekistan, it is necessary to solve some acute problems. These, in our opinion, include the following:

firstly, the allocation of targeted public investment for the formation of innovation clusters;

secondly, in cities with high scientific and technological potential to create centers of innovative development;

third, to provide centers with tax and customs benefits;

fourthly, radically revise the list of specialties in higher educational institutions, taking into account the training of specialists capable of working in centers of innovative development.

\section{REFERENCES}

1. Decree of the President of the Republic of Uzbekistan of 07.02.2017, UP No. 4947 "On the strategy of actions for the further development of the Republic of Uzbekistan."

2. Decree of the President of the Republic of Uzbekistan dated 09.21.2018 "Strategy for innovative development of the Republic of Uzbekistan for 2019-2021".

3. Varnavsky V.G., Klimenko A.V., Korolev V.A. Public-private partnership: theory and practice. M .: SU-HSE, 2010

4. Morkovkin D.Ye. Topical issues of publicprivate partnership in the field of innovative 
CURRENT RESEARCH JOURNAL OF PEDAGOGICS 2(12): 16-21, December

2021 DOI: https://doi.org/10.37547/pedagogics-crjp-02-12-04

ISSN 2767-3278

(C)2021 Master Journals

Crossref dof 81 Google

Accepted 05th December, 2021 \& Published 10 ${ }^{\text {th }}$ December, 2021

development of the economy of Russian regions // Scientific works of the Academy of Management under the President of the Republic of Belarus. Issue 16: At 2 pm, Part 1:

Economics. Minsk, 2014. S. 369-374.

5. Igolkina L.M. Public-private partnership in the innovative development of the economy // Economic sciences. 2013. No. 3. P. 49-52.

6. Emelyanov Yu.S. Public-private partnership: innovation and investment. World and domestic experience. - $\mathrm{M}$.: Book house "LIBROKOM", 2013. 